\title{
Nauczyciele Szkoły Ćwiczeń krakowskiego Pedagogium
}

\author{
Teachers of the Training School \\ of the Pedagogium of Cracow
}

\begin{abstract}
ABSTRAKT
Celem niniejszego opracowania jest przedstawienie nauczycieli Szkoły Ćwiczeń zwiqzanych z krakowskim Pedagogium oraz ukazanie roli, jakq odegrali w kształceniu przyszłych elit intelektualnych Krakowa. W większości przypadków opisano tutaj nauczycieli, którzy zwiqzali swoje całe życie zawodowe ze wspomnianq Szkołą Ćwiczeń, będq̨cq ważnym miejscem zajęć praktycznych dla Państwowego Pedagogium i Państwowej Wyższej Szkoły Pedagogicznej w Krakowie. Takim przykładem może być jej dyrektor Rudolf Hajnos, kierujqcy szkołą w okresie międzywojennym. Szkoła Ćwiczeń krakowskiego Pedagogium mieściła się przy ul. Straszewskiego 22 i poczq̨tkowo była czterooddziałowa szkoła powszechnq. W spisie placówek szkolnych przygotowanym przez Mariana Falskiego w 1933 roku wymieniono ja w grupie państwowych niższych szkół ogólnokształcących o siedmioklasowym cyklu nauczania, z gronem dziewięciu nauczycieli i 127 uczniów. W swoim posiadaniu miała cztery sale lekcyine o niezbył dużej powierzchni. Nauczycieli starano się przedstawić w szerokim kontekście ich pracy pedagogicznej oraz wkładu w proces nauczania. Nie zapomniano też o omówieniu ich pasji oraz osobistych sukcesów naukowych i artystycznych. Przedstawiony tutaj materiał odwołuje się do źródeł, które uzupełniono o publikacje oraz wywiady przeprowadzone z absolwentami Szkoły Ćwiczeń.
\end{abstract}

SLOWA KLUCZOWE Szkoła Ćwiczeń, pedagogika, kadra nauczycielska, wychowankowie, pamięć o szkole

\section{KEYWORDS}

Training School, pedagogy, teaching staff, pupils, memory of the school

SPI Vol. 19, 2016/2

ISSN 2450-5358 e-ISSN 2450-5366 DOI: 10.12775/SPI.2016.2.010 Artykuły i rozprawy 


\section{ABSTRACT}

The aim of this study is to present the profiles of the teachers of the Training School associated with the Pedagogium of Cracow and to show the role they played in the education of the future intellectual elite of Cracow. The paper describes the teachers who tied their professional life with the Training School, an important place for practical classes of the students of the State Pedagogium and the State Pedagogical College of Cracow. As an example one could present Rudolf Hajnos, who was the head of the School in the interwar period. The Training School of the Pedagogium of Cracow was located at 22 Straszewskiego Street and was initially a four-class elementary school. The list of schools prepared by Marian Falski in 1933 listed the school among the state lower general schools of seven-class learning cycle, nine teachers and 127 students. The school owned four modest classrooms and the teachers of the Training School are shown in a broad context of their pedagogical work and contribution to the learning process. Of the same importance are their passions and personal success in scientific and artistic fields. The paper is based on primary source research, supplemented by publications and interviews with graduates from the Training School.

\section{Wprowadzenie}

Szkoła Ćwiczeń krakowskiego Pedagogium mieściła się przy ul. Straszewskiego 22. Najpierw związana była z Seminarium Nauczycielskim Męskim w Krakowie, a po 1946 roku z Państwową Wyższą Szkołą Pedagogiczną w Krakowie ${ }^{1}$. We wrześniu 1928 roku rozpoczęła pracę jako czterooddziałowa szkoła powszechna. W spisie placówek szkolnych przygotowanym przez Mariana Falskiego w roku 1933 wymieniono ją w grupie niższych szkół ogólnokształcących i zaliczono do szkół państwowych o siedmioletnim cyklu nauczania, z gronem dziewięciu nauczycieli i 127 uczniów. Dysponowała czterema salami lekcyjnymi i niezbyt dużą powierzchnią użytkową, użyczoną przez Państwowe Pedagogium² ${ }^{2}$.

1 Na początku była ona szkołą dwuklasową z dwoma nauczycielami i zajmowała pierwsze piętro Pałacu Larischa, mieszczącym się na rogu ul. Brackiej i placu Wszystkich Świętych. Po 1904 roku seminarium nauczycielskie wraz z szkołą ćwiczeń przeniesiono na ul. Straszewskiego 22.

2 Szkoty Rzeczypospolitej Polskiej w roku szkolnym 1930/31, red.M. Falski, Warszawa 1933, s. 370 . 
Wcześniej miejsce było posiadłością należącą do księżnej Marii Ogińskiej, córki hr. Wojciecha Potulickiego.

\section{0 dyrektorze Szkoły Ćwiczeń}

Przez cały okres międzywojenny jej dyrektorem był Rudolf Hajnos, osoba stanowcza, z dużą kulturą osobistą i odpowiednim przygotowaniem pedagogicznym. Wykształcenie nauczycielskie uzyskał w Seminarium Nauczycielskim w Stanisławowie, jednym z lepszych tego typu zakładów kształcenia nauczycieli w Galicji. Swoją pierwszą pracę w wyuczonym zawodzie rozpoczął w Białym Dunajcu na Podhalu. Podczas I wojny światowej walczył pod dowództwem generała Hallera. Niemal w tym samym czasie przeprowadził się do Krakowa i zamieszkał przy ul. Słonecznej, obecnie Bolesława Prusa. Przez pewien czas mieszkał też przy ul. Lelewela. W okresie II wojny światowej rodzinę Hajnosów, jak wielu mieszkańców miasta, Niemcy wykwaterowali. Wraz z najbliższymi znalazła ona wtedy schronienie w niewielkim pokoju na Salwatorze, następnie w wikarówce przy kościele sióstr Norbertanek. Córka dyrektora Hajnosa po latach zapisała:

Wybuch II wojny światowej zniweczył wszystkie plany ojca związane z pracą zawodową, przede wszystkim pozbawił kierowania swoją ukochaną Ćwiczeniówką. Nerwowy wojenny czas, bieda, stan ciągłego zagrożenia odbiły się bardzo na jego zdrowiu. Oczekiwane wyzwolenie przyniosło mu kolejną falę represji, związaną z diametralnie inną orientacją polityczną. Ojciec na nowo zorganizował Ćwiczeniówkę, ale jej dni i jego w niej były policzone ${ }^{3}$.

Rudolf Hajnos był dyrektorem oraz nauczycielem przyrody, geografii oraz języka polskiego. W oparciu o swoje dotychczasowe doświadczenia oraz ogólnie przyjęte przez Ministerstwo Wyznań Religijnych i Oświecenia Publicznego zalecenia wydał w maju 1934 roku materiały metodyczne pozwalające realizować nowe programy nauczania w II klasie szkoły powszechnej. Przede wszystkim miały one służyć one młodym nauczycielom, dając im możliwość zachowaniem samodzielności $\mathrm{w}$ pracy $\mathrm{z}$ uczniem. W centrum programu

3 Por. T. Hajnos-Stawińska, Córka o Ojcu, w: Nasza Szkota. Jednodniówka, Opracowanie poligraficzne wydawane przez Stowarzyszenie Absolwentów Szkoły Ćwiczeń w Krakowie, Kraków 2002, s. 4-6. 
nauczania pozostawał nasz kraj z jego kulturą i środowisko naturalne, które miało pomóc w zdobyciu podstawowych dóbr materialnych i wartości moralnych. Materiał dotyczący środowiska podzielono na cykle tematyczne, dające możliwość zaprezentowania dziecka, domu rodzinnego, szkoły, zjawisk klimatycznych, wody jako źródła życia, zwierząt i roślin, ośrodków życia duchowego oraz instytucji społecznych w postaci szpitali, zakładów wychowawczych i dobroczynnych. Zestawione ze sobą tematy zajęć musiały się uzupełniać i wzajemnie przenikać. Poddając analizie na przykład środowisko i jego krajobraz, starano się dostrzec piękno rzeźby terenu, szatę roślinną oraz jego klimat. W dalszej kolejności przechodzono do przedstawienia sieci głównych wód, świata zwierząt, domów oraz ich mieszkańców. Środowisko naturalne starano się pokazać w kontekście wpływu na zagadnienia gospodarcze, społeczne i polityczne. Natomiast przemysł, wraz z miastami i ludzkimi osadami, łączono z miejscami sprzyjającymi jego rozwojowi. Przy czym pamiętano, że szkoła to jedna z ważniejszych instytucji wychowawczych, które kształtują społeczeństwo i przyszłych obywateli dbających o dobro państwa:

Musimy zatem zastosować metodę, któraby sprzyjała rozwojowi psychiki ucznia, zaprawiała go do pracy samodzielnej, która w przyszłości stałaby się podstawą pracy twórczej. Słowem, mamy zastosować taką metodę, któraby kształtowała jego osobowość. Aby wykształcić osobowość, muszą się znaleźć w środowisku odpowiednie, sprzyjające wychowaniu sytuacje, pobudzające rozwój psychiczny i fizyczny wychowanka ${ }^{4}$.

Rudolf Hajnos nie ukrywał swoich centroprawicowych poglądów. Mimo tego był zwolennikiem koedukacyjności, czyli wspólnych klas dla dziewcząt i chłopców. Należał do Akcji Katolickiej i był pierwszym prezesem Związku Przyjaciół Dzieła Brata Alberta, w ramach którego działa Szkoła Przemysłowa Braci Albertynów, przygotowująca ubogą młodzież do pracy w zawodzie krawca, szewca i introligatora ${ }^{5}$.

4 Por. R. Hajnos, Z doświadczeń nauczyciela realizującego nowe programy w II-giej klasie szkoty powszechnej, Kraków 1934, s. 13.

5 B. Morawska-Nowak, Dyrektor i jego szkota, w: Nasza Szkota. Szkota Ćwiczeń przy Państwowym Seminarium Nauczycielskim Męskim im. Grzegorza Piramowicza. Państwowym Pedagogium. Państwowej Wyższej Szkole Pedagogicznej. Jednodniówka wydana z okazji odstonięcia pamiątkowej tablicy na budynku 


\section{Szkoła Ćwiczeń i jej zwiqzek z krakowskim Pedagogium}

O stosunkowo wysokiej pozycji Szkoły Ćwiczeń w gronie krakowskich szkół powszechnych przesądził jej związek z państwowym Pedagogium, które rozpoczęło swoją działalność w 1928 roku. Powstało ono w oparciu o istniejące wcześniej Państwowe Kursy Nauczycielskie. Pedagogium zajmowało się kształceniem nauczycieli, a „Ćwiczeniówka” z jej dobrą kadrą pozwalała na odbycie praktyk na odpowiednio wysokim poziomie i zdobycie wymaganych umiejętności zawodowych. W Pedagogium prowadzono z początku dwuletni kurs dla osób mających wykształcenie w zakresie sześciu klas gimnazjum oraz roczny dla czynnych nauczycieli oraz tych, którzy ukończyli szkołę średnią. Pierwszy rok nauki miał charakter wprowadzający, w jego trakcie przeważały zajęcia $\mathrm{z}$ religii, języka polskiego z literaturą, matematyki, historii, geografii. W drugim roku nauczano psychologii, pedagogiki, dydaktyki, historii pedagogiki, organizacji szkolnictwa i ustawodawstwa szkolnego, higieny szkolnej oraz ćwiczeń praktycznych, do których zaliczono roboty ręczne, rysunek, muzykę i śpiew, gry i zabawy gimnastyczne. W programie nauczania znalazły się także metodyki przedmiotowe i zajęcia w szkole ćwiczeń. W ramach zajęć szkolnych prowadzano hospitację, obserwację dzieci, lekcje pokazowe oraz brano udział w konferencjach nauczycielskich ${ }^{6}$. $Z$ nowych metod nauczania próbowano wprowadzać zasady planu daltońskiego i metodę projektów. W Szkole Ćwiczeń przeprowadzono kilka eksperymentów naukowych z zakresu pedagogiki, pedeutologii i psychologii. W obrębie psychologii wykonano eksperyment polegający na nakręceniu filmu dokumentalnego pt. Ręce dziecka. Wpisywał się on w ogólny nurt badań prowadzonych przez prof. Stefana Szumana, nazwanych laboratorium obserwacji zdolności manualnych dziecka. Był on bliski szeroko rozumianym zainteresowaniom naukowym Szumana, na które złożyły się psychologia rozwojowa i wychowawcza oraz refleksja nad procesami i funkcjami psychicznymi dziecka ${ }^{7}$.

dawnej Szkoty i spotkania wychowanków w dniu 18 lutego 1995 roku, opracowała Barbara Morawska-Nowak, Kraków 1995, s. 5-11.

6 A. Szumski, $W$ walce o postępowa szkotę. Rzecz o Henryku Rowidzie, Warszawa 1977, s. 213.

7 G. Cisowski, Na początku byta Szkota Ćrwiczeń, w: Nasza Szkota. Szkota Ćwiczeń przy Państwowym Seminarium Nauczycielskim Męskim im. Grzegorza 
Przez ponad 10 lat (1928-1939) dyrektorem Pedagogium był Henryk Rowid, znany w Polsce i świecie teoretyk wychowania, społecznik oraz organizator kształcenia i doskonalenia nauczycieli. W czasie II wojny światowej zaangażowany był w tajne nauczanie oraz w pracę w Okręgowym Biurze Szkolnym związanym z Tajną Organizacją Nauczycielską, gdzie miedzy innymi organizował tajne kursy dokształcające dla nauczycieli.

Po 1945 roku dyrektorem Pedagogium została Wanda Bobkowska, związana jednocześnie ze Studium Pedagogicznym Uniwersytetu Jagiellońskiego. W latach 1931-1939 wykładała w Pedagogium, gdzie była chwalona za szeroką wiedzą i poprawną umiejętność ujmowania zagadnień pedagogicznych. Uczyła głównie historii wychowania. Stefan Wołoszyn, jeden ze znanych historyków wychowania i pedagogów, bardzo wysoko ocenił jej wykłady z zakresu pedagogiki Jana Henryka Pestalozziego, Fryderyka Adolfa Diesterwega, Fryderyka Wilhelma Froebla, Jana Fryderyka Herbarta oraz luźne refleksje na temat Stanisława Kota ${ }^{8}$. Z Pedagogium i Szkołą Ćwiczeń związani byli również Henryk Policht i Józef Życzkowski

\section{W trosce o pamięć o nauczycielach Szkoły Ćwiczeń}

Wśród nauczycieli Szkoły Ćwiczeń krakowskiego Pedagogium wymienić należy: Jana Basta - nauczyciela biologii, Janinę Bińkowską - nauczycielkę języka angielskiego, Tadeusza Bizerskiego nauczyciela prac ręcznych, Jana Cholewińskiego - nauczyciela matematyki, Jerzego Cierniaka - nauczyciela wychowania fizycznego, Stanisława Czchowicza - nauczyciela języka angielskiego, ks. Stanisława Dąbrowskiego - katechetę, Andrzeja Filipka - nauczyciela matematyki, ks. Władysława Gałata - katechetę, Marię Garbaczew-

Piramowicza. Państwowym Pedagogium. Państwowej Wyższej Szkole Pedagogicznej. Jednodniówka wydana z okazji odstonięcia pamiątkowej tablicy na budynku dawnej Szkoty i spotkania wychowanków w dniu 18 lutego 1995 roku, opracowała Barbara Morawska-Nowak, Kraków 1995, s. 40.

8 W. Szulakiewicz, Wanda Bobkowska (1880-1948). Szkic z historii polskiej historiografii edukacyjnej, Rzeszów 1998, s. 25-26.

9 K. Buczek, Nauczyciele krakowskiego Pedagogium w latach 1928-1939, w: $W$ kręgu dawnych $i$ wspótczesnych teorii wychowania. Uczeń - szkota - nauczyciel, red. K. Dormus, R. Ślęczka, Kraków 2012, s. 56-63. 
ską - nauczycielkę matematyki, Edwarda Grygiela - nauczyciela języka polskiego, ks. Szymona Hanuszka - katechetę, Władysława Kłosińskiego - nauczyciela historii, języka polskiego, nauczania początkowego, Franciszka Koniora - nauczyciela śpiewu, Leona Kopycińskiego - nauczyciela języka polskiego i nauczania początkowego, Antoniego Kotulskiego - nauczyciela wychowania fizycznego, Eugeniusza Kozerę - nauczyciela matematyki i nauczania początkowego, Stanisławę Lewicką - nauczycielkę języka polskiego, historii, ks. Jana Litwina - katechetę, ks. Stanisława Mazanka - ks. katechetę, Jadwigę Mrzygłodównę, Jana Pilcha - nauczyciela języka niemieckiego, Henryka Polichta - nauczyciela rysunku, Kazimierę Pollo - nauczycielkę historii, języka polskiego, Teodora Serednickiego - nauczyciela robót ręcznych, Stefana Smiczka - nauczyciela śpiewu, Stanisława Sochę, Helenę Szafrańską - nauczycielkę historii, języka polskiego i nauczania początkowego, Stanisława Wójcika - nauczyciela prac ręcznych, Stefana Zielińskiego - nauczyciela rysunku i Józefa Życzkowskiego.

Prawie od samego początku ze Szkołą Ćwiczeń związana była Kazimiera Pollo, która kształciła się w Prywatnym Seminarium Nauczycielskim Żeńskim w Stanisławowie. W 1916 roku przeniosła się do Krakowa, gdzie miedzy innymi podjęła studia na Uniwersytecie Jagiellońskim. Zaliczyła też wakacyjny kurs w Instytucie Jana Jakuba Rousseau w Genewie. Od 1919 roku pracowała w wspomnianej Szkole Ćwiczeń w Krakowie. Szkoła była jej całym życiem. Pierwsi wychowankowie zapamiętali ją jako nauczycielkę języka polskiego i historii oraz wspaniałą wychowawczynię troszczącą się jednakowo o wszystkich uczniów. Ze szkołą w pierwszym okresie jej istnienia związany był Leon Kopyciński, pochodzący z Żymigrodu. Jeszcze przed I wojną światową otrzymał patent do nauczania w szkołach ludowych i wydziałowych w zakresie języka polskiego, niemieckiego, geografii, historii oraz śpiewu. Miał ukończone konserwatorium w klasie skrzypiec. Śpiewał pięknym basem i należał do Towarzystwa Śpiewaczego Echo i Towarzystwa Operowego.

W rozmowach z żyjącymi absolwentami Szkoły Ćwiczeń najczęściej wymieniano następujących nauczycieli: Jerzego Cierniaka, Jana Bastę, Władysława Kłosińskiego, Eugeniusza Kozerę, Henryka Polichta, Józefa Życzkowskiego. Ten ostatni jeszcze kilka lat temu był jednym dwóch żyjących jeszcze nauczycieli „Ćwiczeniówki”. W szkole pojawił się wtedy, gdy dyrektorem była Wanda Bobkowska, 
która zaraz po II wojnie światowej podjęła trud skompletowania kadry pedagogicznej. Jerzy Cierniak często opowiadał, jak zaraz po wojnie wraz $\mathrm{z}$ uczniami przenosił ławki $\mathrm{z}$ dawnej synagogi. Jan Basta uczył w „Ćwiczeniówce” pod koniec jej funkcjonowania, prowadząc lekcje biologii i fizyki. Zastąpił w niej Andrzeja Filipka. Był postawnym mężczyzną, spokojnym i zrównoważonym. Niezwykle miło wspominano Władysława Kłosińskiego, który pobierał naukę w Seminarium Nauczycielskim w Krakowie, a po jego ukończeniu pracował w kilku krakowskich szkołach powszechnych. Dodatkowo miał zainteresowania muzyczne. $Z$ wynikiem bardzo dobrym ukończył Konserwatorium Muzyczne w Krakowie i w 1906 roku zdał w Pradze egzamin państwowy na nauczyciela muzyki w zakresie skrzypiec i śpiewu. W 1919 roku wydał Elementarz $i$ rachunki dla klasy pierwszej oraz związany z nim przewodnik metodyczny pt. Pierwszy rok nauki. W Szkole Ćwiczeń pracował od 1921 roku. Jego syn scharakteryzował go następująco:

Średniego wzrostu, szczupły, bardzo ruchliwy, nerwowy, szalenie wrażliwy, prawdomówny aż do granic naiwności, sprawiedliwy, uczynny o dużym poczuciu humoru i wybitnej fantazji, trawiony ciaggłym niepokojem intelektualnym o skomplikowanej emocjonalności, szczery patriota o poglądach demokratyczno-lewicowych.

Nauczycielem rysunku i cenionym grafikiem był Eugeniusz Kozera, który ukończył Seminarium Nauczycielskie w Krakowie. W swojej pracy nauczycielskiej posiłkował się kilkoma własnymi opracowaniami z zakresu nauczania elementarnego, między innymi Metodykq gramatyki elementarnej i wspólnie opracowanym z Antonim Mikulskim i Stanisławem Wójcikiem Elementarzem porwszechnym. We wspomnieniach jednego z uczniów znajdujemy następującą charakterystykę Eugeniusza Kozery:

[...] szczupły, wysoki, nienagannie ubrany, opanowany w mowie i ruchach, zawsze pogodny. Na lekcje przynosił sterty pomocy naukowych i skrzypce. Pierwsze miesiące w pierwszej klasie były to zabawy polegające na układaniu kolorowych kółek, trójkątów, patyczków, rysowanie (też jako zadanie domowe), pytania, rozmowy, śpiewanie przy akompaniamencie skrzypiec. Słuchając naszych opowiadań lub odpowiedzi, zwracał uwagę na dykcję i emisję głosu. [...] Mój Ojciec w połowie naszych pierwszoklasowych doświadczeń powiedział wychowawcy, że jest zaniepokojony słabymi postępami synów, bo mija półrocze, a my nie piszemy liter, nie czytamy i nie liczymy. Kozera z całym spokojem zapewnił, że do końca roku opanujemy te umiejętności. I tak się stało. Dziś tę metodę 
określiłbym skrótem UBW: Uczy-Bawi-Wychowuje. Przy pomocy lekcji rysunku układał nam rękę do ołówka i pióra, uczył kreślenia łuków, kółek. Z patyczków układaliśmy litery, cyfry, liczyliśmy je. Przerywnikami tych ćwiczeń był śpiew przy akompaniamencie jego skrzypiec ${ }^{10}$.

O swoim wychowawcy, Eugeniuszu Kozerze, po wielu latach z dużą sympatią opowiadał też Tadeusz Godzicki, uczeń z lat 19251929. Odbierał go jako niezwykle eleganckiego nauczyciela, wspaniałego pedagoga, który starał się zakorzenić w uczniach chęć zdobywania wiedzy i ciekawość do otaczającego świata ${ }^{11}$.

Pasją nauczycielską Henryka Polichta było rozwijanie wśród uczących się dzieci uzdolnień artystycznych, głównie plastycznych. W zakresie posiadanego wykształcenia miał patent do nauczania rysunku i robót ręcznych w szkołach ludowych i wydziałowych. Warto w tym miejscu wspomnieć, że studiował rysunek i malarstwo w Akademii Sztuk Pięknych, miedzy innymi pod kierunkiem Józefa Mehoffera. Zanim stał się nauczycielem Szkoły Ćwiczeń, był nauczycielem Państwowych Kursów Nauczycielskich prowadzonych przez Henryka Rowida, a następnie krakowskiego Pedagogium, gdzie od 1932 roku pełnił funkcję zastępcy dyrektora. W 1954 roku zatrudniony został jako asystent, a następnie wykładowca na Wydziale Geograficzno-Biologicznym w Państwowej Wyższej Szkole Pedagogicznej w Krakowie. Należał do kilku miejscowych i ogólnopolskich artystycznych stowarzyszeń, między innymi do Towarzystwa Przyjaciół Sztuk Pięknych i Towarzystwa Zachęty Sztuk Pięknych w Warszawie. W swojej pracy z uczniami zachęcał ich do malowania pejzaży, martwej natury i portretów ${ }^{12}$.

Nauczyciele „Ćwiczeniówki” powiązani byli zawodowo z innymi szkołami: Państwowym Pedagogium, Państwową Wyższą Szkołą Pedagogiczną i kilkoma krakowskimi placówkami poziomu podstawowego i średniego, czego przykładem mógł być Józef Życzkowski uczący tutaj śpiewu. Prowadził on chóry szkolne w szkole powszech-

10 A. Manecki, Eugeniusz Kozera, w: Państwowe Pedagogium i Szkota Ćrwiczeń w Krakowie. Z tradycji ksztatcenia nauczycieli, koncepcja, wybór tekstów i ilustracji Jan Krukowski, Barbara Morawska-Nowak, Kraków 2011, s. 76-80.

11 Rozmowa przeprowadzona z Tadeuszem Godzickim w obecności Barbary Morawskiej-Nowak, Ryszarda Ślęczki i studentek Uniwersytetu Pedagogicznego w Krakowie, Eweliny Tokarczyk i Martyny Szewczuk.

12 Państwowe Pedagogium i Szkota Ćrwiczeń w Krakowie, dz. cyt., s. 91-95. 
nej św. Floriana w Krakowie, Państwowym Liceum Pedagogicznym oraz Pedagogium i PWSP. Z myślą o swoich uczniach wydał wiele śpiewników i podręczników do nauczania śpiewu, m.in.: Śpiewnik szkolny-pieśni bistoryczne, Wybór pieśni dla klas I, II, III oraz Metodykę nauczania śpiewu w klasach I-IV. Mógł się pochwalić bogatą działalnością artystyczną rozpoczętą w 1921 roku w Chórze Akademickim w Krakowie, gdzie dyrygował orkiestrą. Ze wspomnianym chórem wystąpił w Watykanie, dając koncert dla Ojca Świętego Piusa XI. W PWSP uczyli ponadto Tadeusz Bizerski i Stanisław Czechowicz.

W szkole pracowało także kilku katechetów. Jednym z nich był ksiądz Władysław Gałat, urodzony w podkrakowskim Bieżanowie. Po ukończeniu gimnazjum im. Jana Matejki w Wieliczce wstąpił do seminarium ojców pijarów w Pińsku. Następnie odbył studia w zakresie teologii w Uniwersytecie Jagiellońskim i wystąpił ze zgromadzenia ojców pijarów. Jako ksiądz diecezjalny rozpoczął pracę katechety w omawianej przez nas szkole. Po jej zamknięciu w 1951 roku został rektorem kościoła św. Wojciecha w Rynku Głównym w Krakowie. Uczniowie zapamiętali go jako człowieka o niewielkim wzroście, ale lubiącego ruch i sportową rywalizację. $Z$ większością potrafil nawiązać bliski kontakt i miał duże poczucie humoru ${ }^{13}$. Wspomnieć należy też księdza Jana Litwina, który do Krakowa przyjechał z Podlesia, niewielkiej miejscowości położonej koło Mielca. Studiował na Wydziale Teologicznym UJ i w 1925 roku zdał egzamin dający możliwość prowadzenia katechezy w szkołach średnich. W roku 1931 obronił doktorat $\mathrm{z}$ teologii na UJ. W prowadzonej przez siebie katechezie był niezwykle wymagający, dbając o religijność wychowanków. Starał się pilnować, aby uczniowie wraz z rodzicami uczestniczyli w każdą niedziele w mszy świętej odprawianej w szkole. $Z$ dużym powodzeniem angażował się $\mathrm{w}$ działalność stowarzyszenia religijnego pod nazwą Krucjata Eucharystyczna ${ }^{14}$.

Wraz z kadrą nauczycielską dyrektor Rudolf Hajnos stworzył w szkole niepowtarzalną atmosferę. Stała się ona miejscem kształcenia i wychowania krakowskich elit. Wśród jej wychowanków znalazło się wiele wybitnych osób z życia społecznego i politycznego,

13 J. Ciećkiewicz, Ksiądz Wtadystaw Gatat, w: Państwowe Pedagogium i Szkoła Ćwiczeń w Krakowie, dz. cyt., s. 69-70.

14 J. Małecki, Ksiqdz Jan Litwin, w: Państwowe Pedagogium i Szkota Ćrwiczeńn w Krakowie, dz. cyt., s. 88-90. 
duchownych, ludzi nauki i kultury, adwokatów i inżynierów ${ }^{15}$. Poszukując odpowiednich wzorców, odwoływano się do jej pierwszych absolwentów, takich jak Stanisław Estreicher, Józef Mehoffer i Stanisław Wyspiański ${ }^{16}$. Na zachowanych listach uczniów Szkoły Ćwiczeń pojawiły się nazwiska dzieci ze znanych rodzin krakowskich, między innymi prawniczej rodziny Zollów i wielu innych. Uczyli się tutaj Fryderyk i Józef Zoll. Nie sposób wymienić wszystkich. Znany nam jest dokładny wykaz uczniów Szkoły Ćwiczeń, z podziałem na roczniki i klasy, autorstwa Barbary Morawskiej-Nowak, zaczęła być tworzona z początkiem roku szkolnym 1947/48.

Podczas okupacji niemieckiej szkoła przeżywała trudne chwile. W związku z likwidacją Pedagogium i całego szkolnictwa średniego szkoła miała duże trudności z właściwym funkcjonowaniem. W książce Andrzeja Kijowskiego pt. Kronika Dedala czytamy:

Przed wojną wszyscy lecieli na podwórko bawić się w Zawiszę Czarnego pod Grunwaldem, Chodkiewicza pod Kircholmem, w Żółkiewskiego pod Cecorą, zależnie od tego, cośmy przerabiali na historii. Teraz na podwórku esesmani musztrowali Ukraińców ochotników, z których robili przyszłą SS-Galizien. [...] Dyrektor Hajnos był w złym stanie. Brakowało węgla na opał. Musiał zdobywać go własnym przemysłem,

15 Ze znanych ludzi świata nauki, kultury i kościoła, którzy ukończyli Szkołę Ćwiczeń, wymienić wypada: Franciszka Macharskiego - kardynała metropolitę krakowskiego, Mieczysława Kluzę - karmelitę, doktora prawa, Mieczysława Turka - prałata w parafii św. Anny, Otmara Giedliczkę - chirurga, prof. Collegium Medicum UJ, Jerzego Gierulę - fizyka, prof. AGH, Kazimierza Godłowskiego - archeologa, prof. UJ, Stanisława Grzybowskiego - historyka, prof. WSP w Krakowie (obecnie Uniwersytet Pedagogiczny), Jana Małeckiego - historyka gospodarczego, prof. AE (obecnie Uniwersytet Ekonomiczny), Andrzeja Maneckiego - górnika, geologa, prof. AGH, Zbigniewa Kwiatkowskiego - mikrobiologa, prof. UW, Adama Miodońskiego neuroanatomistę, laryngologa, prof. Collegium Medicum UJ, Jacka Mościńskiego - fizyka, informatyka, prof. AGH, Andrzeja Nadolskiego - historyka, archeologa, prof. UŁ, Janusza Orkisza - inżyniera budownictwa, prof. PK, Krzysztofa Pigonia - chemika fizycznego, prof. Uniwersytetu Wrocławskiego, Jana Pierożyńskiego - historyka, prof. UJ, Andrzeja Szczeklika - lekarza chorób wewnętrznych, prof. Collegium Medicum UJ, Jerzego Szczeklika lekarza kardiologa, prof. Collegium Medicum UJ, Jerzego Vetulaniego - biochemika, psychofarmakologa, prof. PAN i wielu innych.

16 Państwowe Pedagogium. Państwowa Wyższa Szkota Pedagogiczna. Wyższa Szkota Pedagogiczna. Akademia Pedagogiczna im. Komisji Edukacji Narodowej. Najstarsza Uczelnia Pedagogiczna w Polsce, koncepcja, opracowanie tekstów, wybór ilustracji Jan Krukowski, Kraków 2006, s. 152. 
nieraz na kilka dni tylko. Często przychodząc do szkoły, zastawaliśmy go stojącego przed szkołą obok wartownika i słyszeliśmy znaną formułę: idź, mały do domu, przyjdź za parę dni. Mówił to zgnębionym głosem, jakby sam temu zawinił. Ponadto naszej szkole grożono wyrzuceniem z budynku. Ukraińscy ochotnicy dostali już broń i esesmańskie mundury, było ich coraz więcej, ich śpiew przeszkadzał nam w lekcjach. $Z$ drugiej strony, od resursy obywatelskiej, z którą szkoła się stykała ścianami, groziła zielona policja. Dyrektor wychodził ze skóry, żeby uratować budynek, sprzęty, zbiory ${ }^{17}$.

Okupant wprowadził poważne ograniczenia w programach nauczania. Szkołę usunięto ze swojego budynku i przeniesiono na ul. Smoleńsk.

W czasie ferii wielkanocnych 1940 roku przybiegł do mnie kolega z rozkazem od dyrektora Hajnosa, abym zaraz przyszedł do szkoły z teczka$\mathrm{mi}$, torbami i workami, jakie tylko w domu znajdę, bo szkołę wyrzucają i trzeba ją w ciągu trzech dni przenieść do szkoły na Smoleńsk. Biegając tam i z powrotem, jak mrówki pomiędzy starym, zburzonym mrowiskiem a nowym, przenieśliśmy w rękach krzesła, stoliki, katedry, książki, wypchane ptaki i zwierzaki, kolby i próbówki, mapy i globusy. Odtąd lekcje odbywały się popołudniu, w obcym budynku, którego wszystkie korytarze i kąty zapchane były naszymi rzeczami ${ }^{18}$.

Następnie usytuowano szkołę przy ul. Stradom, w dawnej żydowskiej dzielnicy, z której mieszkańców wysiedlono do getta. Dyrektora Hajnosa zastąpił Foryś (od 1942 roku), który popsuł miłą atmosferę panującą w szkole. Jego osoba nie zapisała się dobrze w pamięci wychowanków i nauczycieli.

Po II wojnie światowej szkoła wróciła do swojego dawnego budynku przy ulicy Straszewskiego. W nazwie nie pojawił się jej wcześniejszy patron, Grzegorz Piramowicz. Ten okres bardzo ciepło wspomina Grzegorz Cisowski:

Przenieśliśmy się na ul. Straszewskiego 22 z budynku przy ul. Grodzkiej $60 \mathrm{w}$ zimie $1946 \mathrm{r}$. Siedzieliśmy tam na krzesłach przyniesionych z domu, bo całe wyposażenie było zniszczone. W zimie raz w tygodniu uczeń miał przynieść jedno wiadro węgla do palenia w piecach. Przeprowadzkę wykonaliśmy sami. Niosłem jaką́s sowę czy puchacza pod Wawel, a potem plantami pod Collegium Novum. Po kilku dniach uporządkowaliśmy mapy, salę przyrodniczą i zaczęła się nauka. Lekcje zaczynały się od modlitwy

17 A. Kijowski, Kronika Dedala. Szkice i kroniki, Warszawa 1986, s. 206-208.

18 Tamże, s. 256-257. 
do Ducha Świętego, aby oświecał umysły nasze. Bardzo na to liczyłem, bo wszystko było trudne, nowe, obce. $Z$ tych lekcji najbardziej pamiętam panią Garbaczewską, której baliśmy się, bo była bardzo wymagająca, ale też szanowaliśmy ją bardzo. Prowadziła z nami wszystkie lekcje z wyjątkiem religii, prac ręcznych, śpiewu i gimnastyki. Religia to pierwszy kontakt z Panem Tadeuszem - nieprzygotowanie lekcji z religii karane było księgą Pana Tadeusza na pamięć, a ks. Gałat wołał: Grzechu do odpowiedzi! Nie byłem zadowolony z tego przezwiska. Prof. Smiczka grał na skrzypcach. Ustawiał nas w klasie w półkole według głosów i wzrostu, stroił skrzypce, podawał ton i grając dyrygował śpiewem. Pamiętam go na tle jasno oświetlonego okna z pogodną twarzą, poprawiającego nasze mizerne głosy ${ }^{19}$.

Z powojenną historią szkoły, o czym była już wcześniej mowa, losy swoje związał Jerzy Cierniak. Zachęciła go do współpracy Wanda Bobkowska, kompletująca zespół nauczycieli. W szkole prowadził on zajęcia $z$ wychowania fizycznego, w których chętnie uczestniczyli uczniowie. Pełnił jednocześnie funkcję kierownika sekcji Wychowania Fizycznego w Wojewódzkim Ośrodku Metodycznym w Krakowie oraz był wizytatorem metodycznym w Kuratorium Okręgu Szkolnego w Krakowie. Pracował też w Zakładzie Metodyki Wychowania Fizycznego w Wyższej Szkole Pedagogicznej i Akademii Wychowania Fizycznego. Poświęcił się pracy naukowej i uczestniczył w opracowaniu kilku podręczników dla nauczycieli wychowania fizycznego.

\section{Zakończenie}

W pierwszych latach PRL szkołę nadal postrzegano jako elitarną. Zasadniczo nie wpisywała się ona w przyjęty przez państwo nurt nowej ideologii. Szkole zazdroszczono niezłej pozycji, głównie z powodu związku z krakowską PWSP, i wysyłano na nią wiele anonimów kierowanych do administracji szkolnej i władz politycznych. Przedmiotem zawiści było dysponowanie nieco większymi środkami finansowymi, zdolniejszą młodzieżą, niewielką liczebnością oddziałów klasowych oraz możliwością uzyskania zniżki godzinowej przez nauczycieli. O ostatecznym losie szkoły zdecydowała sytuacja polityczna oraz - jak wtedy mówiono - czynniki partyjne:

19 G. Cisowski, Na poczq̨tku byta Szkota Ćrwiczeń, w: Nasza Szkota, dz. cyt., s. 40-43. 
Jeszcze wcześniej, za dyrektora Hajnosa, odwiedził Szkołę Ćwiczeń ówczesny minister Oświaty dr Stanisław Skrzeszewski i kazał dzieciom robotników podnosić ręce w klasach. Było ich mało, dlatego od dawna ta ówczesnym władzom zaczęła się nie podobać, mimo że $\mathrm{w}$ niej wdrażano do zawodu nauczycielskiego z WSP, UJ, ASP ${ }^{20}$.

W pewnym sensie o losach szkoły przesądziły też decyzje, jakie zapadły w Ministerstwie Oświaty i we władzach Państwowej Wyższej Szkoły Pedagogicznej w Krakowie. Powiązanie likwidacji szkoły z osobą rektora Wincentego Danka nie do końca wydaje się słuszne, gdyż - według ogólnie przyjętych przez państwo zasad PWSP musiało zmienić swój podstawowy profil i skupić się na kształceniu nauczycieli szkół średnich. Szkołą, do której kierowano na praktyki studentów, stało się I Liceum Ogólnokształcące im. Bartłomieja Nowodworskiego tzw. „Nowodworek”. W opisanym przypadku nie bez znaczenia była reforma szkolnictwa ogólnokształcącego, zmierzająca do wprowadzenia szkoły jedenastoletniej, jednolitej pod względem organizacyjnym i programowym. O ostatecznej likwidacji szkoły poinformowano uczniów i rodziców w piśmie przesłanym przez Wydział Oświaty Prezydium Miejskiej Rady Narodowej w dnia 14 sierpnia 1951 roku. Majątek szkoły wraz z całą dokumentacją przekazano szkole przy ul. Szujskiego, a nauczycieli przeniesiono do kilku krakowskich szkół podstawowych.

\section{BIBLIOGRAFIA}

Bizerski T, Zmierzch szkoty, w: Nasza Szkota. Szkota Ćrwiczeń przy Państwowym Seminarium Nauczycielskim Męskim im. Grzegorza Piramowicza. Pañstwowym Pedagogium. Pañstwowej Wyższej Szkole Pedagogicznej. Jednodniówka wydana z okazji odstonięcia pamiątkowej tablicy na budynku dawnej Szkoty i spotkania wychowanków w dniu 18 lutego 1995 roku, opracowała Barbara Morawska-Nowak, Kraków 1995.

Buczek K., Nauczyciele krakowskiego Pedagogium w latach 1928-1939, w: W kregu dawnych $i$ wspótczesnych teorii wychowania. Uczeñ - szkotanauczyciel, red. K. Dormus, R. Ślęczka, Wydział Pedagogiczny Uniwersytetu Pedagogicznego im. KEN w Krakowie, Kraków 2012.

T. Bizerski, Zmierzch szkoty, w: Nasza Szkoła, dz. cyt., s. 49-52. 
Ciećkiewicz J., Ksiądz Wtadystaw Gatat, w: Państwowe Pedagogium i Szkota Ćwiczeń w Krakowie. Z tradycji ksztatcenia nauczycieli, koncepcja, wybór tekstów i ilustracji Jan Krukowski, Barbara Morawska-Nowak, Wydawnictwo Naukowe UP w Krakowie, Kraków 2011.

Cisowski G., Na początku byta Szkota Ćwiczeń, w: Nasza Szkota. Szkota Ćwiczeń przy Państwowym Seminarium Nauczycielskim Męskim im. Grzegorza Piramowicza. Państwowym Pedagogium. Państwowej Wyższej Szkole Pedagogicznej. Jednodniówka wydana z okazji odstonięcia pamiatkowej tablicy na budynku dawnej Szkoty i spotkania wychorwanków w dniu 18 lutego 1995 roku, opracowała Barbara Morawska-Nowak, Kraków 1995.

Cisowski G., Na poczq̨tku byta Szkota Ćwiczeń, w: Nasza Szkota. Szkota Ćwiczeń przy Państwowym Seminarium Nauczycielskim Meskim im. Grzegorza Piramowicza. Państwowym Pedagogium. Państwowej Wyższej Szkole Pedagogicznej. Jednodniówka wydana z okazji odstonięcia pamiątkowej tablicy na budynku dawnej Szkoty i spotkania wychowanków w dniu 18 lutego 1995 roku, opracowała Barbara Morawska-Nowak, Kraków 1995.

Hajnos R., Z doświadczeń nauczyciela realizującego nowe programy w II-giej klasie szkoty powszechnej, Drukarnia Polska w Krakowie, Kraków 1934.

Hajnos-Stawińska T., Córka o Ojcu, w: Nasza Szkota. Jednodniówka, opracowanie poligraficzne wydawane przez Stowarzyszenie Absolwentów Szkoły Ćwiczeń w Krakowie, Kraków 2002.

Kijowski A., Kronika Dedala. Szkice i kroniki, „Czytelnik”, Warszawa 1986. Małecki J., KsiądzJan Litwin, w: Państwowe Pedagogium i Szkoła Ćwiczeń w Krakowie. Z tradycji ksztatcenia nauczycieli, koncepcja, wybór tekstów i ilustracji Jan Krukowski, Barbara Morawska-Nowak, Wydawnictwo Naukowe UP w Krakowie, Kraków 2011.

Manecki A., Eugeniusz Kozera, w: Państwowe Pedagogium i Szkota Ćwiczeń w Krakowie. Z tradycji ksztatcenia nauczycieli, koncepcja, wybór tekstów i ilustracji Jan Krukowski, Barbara Morawska-Nowak, Wydawnictwo Naukowe UP w Krakowie, Kraków 2011.

Państwowe Pedagogium. Państwowa Wyższa Szkota Pedagogiczna. Wyższa Szkota Pedagogiczna. Akademia Pedagogiczna im. Komisji Edukacji Narodowej. Najstarsza Uczelnia Pedagogiczna w Polsce, koncepcja, opracowanie tekstów, wybór ilustracji Jan Krukowski, Wydawnictwo Naukowe UP w Krakowie, Kraków 2006.

Państwowe Pedagogium i Szkota Ćrwiczeń w Krakowie. Z tradycji ksztatcenia nauczycieli, koncepcja, wybór tekstów i ilustracji Jan Krukowski, Barbara Morawska-Nowak, Wydawnictwo Naukowe UP w Krakowie, Kraków 2011.

Szkoty Rzeczypospolitej Polskiej w roku szkolnym 1930/31, red. M. Falski, Państwowe Wydawnictwa Książek Szkolnych we Lwowie, Warszawa 1933. 
Szulakiewicz W., Wanda Bobkowska (1880-1948). Szkic z bistorii polskiej bistoriografi edukacyjnej, Wydawnictwo WSP w Rzeszowie, Rzeszów 1998.

Szumski A., W walce o postępowq szkotę. Rzecz o Henryku Rowidzie, PWN, Warszawa 1977.

\section{ADRES DO KORESPONDENCJI}

Dr Ryszard Ślęczka

Uniwersytet Pedagogiczny w Krakowie

Wydział Pedagogiczny, Instytut Pedagogiki Przedszkolnej i Szkolnej

ryslen@up.krakow.pl 